\title{
Strategi Optimalisasi Program Penanggulangan Kerentanan Kemiskinan (Studi Kasus Program Jalinmatra PK2 Di Desa Ngroto Kecamatan Pujon Kabupaten Malang)
}

\author{
Optimalization Strategy of Poverty Vulvenary Reduction Program \\ (Case Study of Jalinmatra PK2 Program on Ngroto Village Pujon \\ Distric Malang Regency)
}

Yudiyanto Tri Kurniawan

Badan Penelitian dan Pengembangan Provinsi Jawa Timur

DOI:https://doi.org/10.32781/cakrawala.v12i1.267

\begin{abstract}
Received : 27 Januari 2018
Accepted : 9 Mei 2018

Published : 21 Mei 2018
\end{abstract}

\begin{abstract}
Abstrak:
Program Jalinmatra Penanggulangan Kerentanan Kemiskinan (PK2) dilaksanakan Pemerintah Provinsi Jawa Timur untuk meningkatkan ketahanan ekonomi rumah tangga rentan miskin dalam bentuk pinjaman murah melalui Badan Usaha Milik Desa (BUMDes), salah satu penerimanya adalah Desa Ngroto yang dimulai Juni 2016. Karena sudah lebih dari satu tahun maka perlu dievaluasi pelaksanaannya dan dampaknya, selanjutnya dirancangkan strategi untuk mengoptimalkannya. Kita menggunakan metode penelitian kualitatif deskriptif, melalui wawancara mendalam, kuisioner, dokumentasi dan observasi lapangan. Hasilnya dapat disimpulkan bahwa untuk mengoptimalkan program ini mereka perlu bantuan untuk penguatan permodalan, teknologi, informasi perdagangan, manajeman usaha dan bantuan jaringan profesional.
\end{abstract}

Katakunci : Optimalisasi, Jalinmatra PK2, Rumah tangga, rentan miskin, BUMDes

\begin{abstract}
Abstrac :
Poverty Vulvenary Reduction Program run by East Java Goverment for increase economic strengtening of vulvenary household with cheap bond through Village Owned Business Entity (VOBE). One of recepient is Ngroto Village, which start on June 2016. It run more than a year, so we need to evaluate the implementation and the effect, than we design the optimalization strategy. We use descriptive qualitative research, with Indepth interview, quisioner, dokumentation and fied observation. Conclution of result is they need help to optimize with additional funds, tecnology, market informations, business management and help from profesionals network.
\end{abstract}

Keywords : Optimalization, Jalinmatra PK2, Household, Vulvenary Poverty, Village Owned Business Entity

How to Cite:

Yudiyanto Tri Kurniawan (2018). Strategi Optimalisasi Program Penanggulangan Kerentanan Kemiskinan (Studi Kasus Program Jalinmatra PK2 di Desa Ngroto Kecamatan Pujon Kabupaten Malang). Cakrawala, 12(1), 97-105. 


\section{Pendahuluan}

Angka kemiskinan di Provinsi Jawa Timur pada kurun waktu antara 2014 ke 2015 terjadi kenaikan sebesar 0,06 poin persen. Padahal pada tahuntahun sebelumnya selalu terjadi penurunan. Dan jika kita ingat pada 18 November 2014 telah terjadi kenaikan harga BBM jenis Bensin Premium sebesar 31\% danSolar sebesar 36\%, yang berdampak turut naiknya hampir semua kebutuhan masyarakat. Hal ini menunjukkan masih lemahnya ketahanan ekonomi keluarga di Provinsi Jawa Timur. Terutama rumah tangga hampir miskin atau rentan miskin di Jawa Timur, sehingga sedikit saja ada perubahan ekonomi, mereka dapat menjadi miskin atau mungkin menjadi sangat miskin.

Harniati $(2007: 100)$ menyatakan Kerentanan kemiskinan menjelaskan bahwa walaupun dari kemampuan konsumsinya di atas garis kemiskinan tetapi berpotensi besar untuk jatuh ke golongan rumah tangga miskin. Untuk rumah tangga seperti ini diperlukan adanya suatu sistem keterjaminan sosial.

Pada Anonimous (2017:45) dinyatakan berdasarkan data BPS antara tahun 2009 dan 2010 sekitar 55,7\% penduduk miskin tahun 2009 keluar dari kemiskinan pada tahun 2010. Sebaliknya terdapat kelompok yang tidak tergolong miskin tahun 2009, yaitu 21,52\% RTHM, 11,54\% RTHTM, dan 2,94\% RTTMjatuh ke dalam kemiskinan pada tahun 2010

Hal serupa tampak pada Dariwardani (2014: 7) dalam analisis dinamika kemiskinan (Poverty Dynamics) di Bali berdasarkan data susenas panel 2008 - 2010 menyatakan Provinsi Bali 1,86 persen penduduknya mengalami kemiskinan kronis selama kurun waktu 2008 - 2010, sedangkan sebanyak 8,69 persen rumahtangga di Bali mengalami kerentanan terhadap kemiskinan (miskin sementara).

Untuk itu Pemerintah Provinsi Jawa Timur mencanangkan program Jalin Matra Penanggulangan Kerentanan Kemiskinan (PK2) yang diperuntukkan peningkatan keberdayaan Rumah Tangga rentan miskin. Program ini digulirkan mulai tahun 2015 hingga 2018, yang secara khusus membidik rumah tangga dengan status kesejahteraan Desil 2 dan 3 (11-30\% terendah pada Data PBDT 2015), atau Rumah Tangga Sasaran (RTS) di wilayah pedesaan. Program ini berupa pemberian dana pinjaman murah kepada RTS melalui Badan Usaha Milik Desa (BUMDes). Dana tersebut diperuntukkan sebagai tambahan modal usaha dan untuk menambah aset RTS, dana ini sifatnya bergulir dengan RTS lain di desa yang sama.

Program ini menargetkan 700 desa yang memiliki minimal 200 rumah tangga rentan miskin (Desil 2 dan 3) yang memiliki potensi sumberdaya alam yang dapat dikembangkan, baik yang sudah memiliki BUMDesa maupun belum namun berpotensi dibentuk BUMDes sesuai dengan Anonimous (2017:10). Hingga akhir tahun 2017 pelaksanaan program Jalinmatra PK2 sudah mencapai 487 desa (69,57\%), sisanya akan diselesaikan pada tahun 2018.

Salah satu desa penerima program ini adalah Desa Ngroto Kecamatan Pujon Kabupaten Malang, yang memiliki 264 rumah tangga desil 2 dan 243 rumah tangga desil 3 atau memiliki 507 rumah tangga rentan miskin. Di desa ini Program Jalinmatra PK2 dimulai pada Juni 2018. Pada tahap awal ada 35 RTS yang mempunyai usaha atau akan membuka usaha yang menerima pinjaman murah sesuai kebutuhan untuk pengembangan usahanya.

Pada nurmayanti (2017:1) tentang efektivitas Program Jalin Matra Penanggulangan Kerentanan Kemiskinan di Desa Ngroto Kecamatan Pujon Kabupaten Malang, hasil penelitiannya menunjukkan: 1) efektivitas Program Jalin Matra PK2 dilihat dari aspek pendapatan berjalan kurang efektif. 2) efektivitas Program Jalin Matra PK2 dilihat dari aspek produksi sudah berjalan efektif. 3) Dari 477 rumah tangga sasaran yang terdaftar dalam kategori rumah tangga hampir miskin, sejauh ini yang dapat memperoleh pinjaman berjumlah 49 rumah tangga $(10,27 \%)$ sehingga pelaksanaan Program Jalin Matra PK2 dilihat dari aspek permodalan dapat dikatakan belum efektif. Untuk itu perlu dipertimbangkan untuk meningkatkan efektifitasnya.

Pada Anonimous (2016:91) menunjukkan secara rerata dampak implementasi program Jalin Matra PK2 terhadap peningkatan pendapatan RTS di lokasi penelitian (Kabupaten Malang, Madiun, Jember dan Sumenep) menunjukkan hasil yang memuaskan (63\%). Dan pencapaian besaran peningkatan pendapatan pada RTS paling banyak antara Rp.500.000 - <Rp.1000.000 (54\%) dan kurang dari Rp.500.000 (42\%) dan hanya 4\% yang mencapai Rp.1000.000 $<$ Rp.2.000.000,-. Jadi sebagian besar RTS mampu memperoleh tambahan pendapatan kurang dari 
Rp.1.000.000,-, yang jika dibagi rata-rata 4 anggota per rumah tangga, maka rata-rata per orang memperoleh peningkatan kurang dari Rp.250.000,-. Sedangkan Garis kemiskinan Provinsi Jawa Timur pada tahun 2017 sebesar Rp.360.302,- perkapita perbulan.

Saat ini lebih dari satu tahun berjalannya program Jalinmatra PK2 di BUMDes ini perlu adanya evaluasi terhadap implementasinya, dampaknya pada usaha RTS penerima program dan selanjutnya perlu dirancangkan strategi alternatif untuk mengoptimalkannya.

Karena alternatif strategi yang dirancangkan tersebut pemanfaatnya adalah RTS yang sudah memiliki usaha, maka dasar pengembangannya menggunakan model pengembangan Inkubator Bisnis Amiaty (2006:11) yang meliputi layanan "7S", yaitu: space, shared, services,support, skill development, seed capital, dan synergy. Karena usaha yang dimiliki RTS tersebut merupakan suatu bentuk "embrio" yang perlu dukungan untuk pengembangannya.

\section{Rumusan Masalah}

1. Bagaimana Implementasi Program Jalinmatra PK2 di Desa Ngroto?

2. Bagaimana dampak Program Jalinmatra PK2 pada usaha RTS di Desa Ngroto?

3. Bagaimana strategi optimalisasi Program Jalinmatra PK2 di Desa Ngroto?

\section{Metode Penelitian}

Penelitian ini merupakan penelitian Kualitatif Deskriptif dengan teknik Studi kasus. Pengumpulan data dilakukan dengan teknik:

1. Wawancara mendalam (Deep Interview), untuk memperoleh data primer dari pejabat terkait di Dinas Pemberdayaan Masyarakat Kabupaten Malang, Kantor Kepala Desa Ngroto, Pengurus BUMDes Ageng dan Tenaga Pendamping MasyarakatKabupaten Malang.

2. Kuisioner untuk para RTS penerima program Jalinmatra PK2 gelombang pertama dari BUMDes sebanyak 30 orang.

3. Observasi lapangan, untuk mengetahui kondisi lingkungan RTSM dan Kondisi Bantuan.

4. Dokumentasi, dengan data Sekunder, didapatkan dari:

a) Data statistik dari Kantor BPS Propinsi Jawa Timur, b) Data Penerima Program Jalinmatra PK2 dari BUMDes Ngroto,

c) Data Pendukung/Pelengkap dari Kantor Dinas Pemberdayaan Masyarakat dan Desa Kabupaten Malang dan Kantor Kepala Desa Ngroto, serta

d) Data-data pendukung lainnya dari website/internet.

Sedangkan untuk mendapatkan informasi semaksimal mungkin disini kami menggunakan Metode Pengambilan Sample dengan metode Purposive, yaitu pemilihan secara langsung dari daftar penerima program Jalinmatra PK2 di Kantor BUMDes Ageng Desa Ngroto.

Kuisioner dibuat dengan menguraikan komponen-komponen 7S Inkubator bisnis, diidentifikasi tingkat kepentingannya pada pengembangan usaha RTS dan kondisi yang dimiliki RTS pada faktor-faktor tersebut. Kuisioner menggunakan 4 skala linkert (Kurang, sedang, baik dan sangat baik).

\section{Hasil dan Pembahasan}

Informan yang kami gali data primernya dapat dikelompokkan berdasarkan statusnya yaitu kelompok Aparatur Daerah yang terkait implementasi Program Jalinmatra PK2 dan Masyarakat sebagai RTS penerima program.

Tabel 1. Pengelompokan Informan

\begin{tabular}{lrr}
\hline \multicolumn{1}{c}{ Status } & Jumlah & Persentase \\
\hline Aparatur Daerah & 10 & 25 \\
\hline Masyarakat & 30 & 75 \\
\hline Total & 40 & 100,0 \\
\hline
\end{tabular}

Sumber : Data Primer diolah

Sedangkan jika diuraikan berdasarkan jenis kelamin informannya terdiri dari 1 orang Perempuan dan 9 orang laki-laki untuk aparatur daerahnya, serta 5 orang perempuan dan 25 orang masyarakat sebagai RTS penerima programnya. Dari hasil olah dan analisa data primer dan sekunder dapat dijelaskan sebagai berikut:

\section{Implementasi program JALINMATRA PK2 di Desa Ngroto}

BUMDesa Ageng didirikan pada tanggal 12-122015, yang diinisiasi untuk melaksanakan program Jalinmatra PK2 di Desa Ngroto. Pada awal pendiriannya hanya mengelola unit simpan pinjam dari Program Jalinmatra Penanggulangan Kerentanan Kemiskinan (SP-JMPK2) tersebut. 
Penetapan RTS masih berdasarkan data PPLS 2011 by name by address yang jumlah total sasarannya 477 rumah tangga hampir miskin saat itu. Danjika kita melihat pada data Program Basis Data Terpadu tahun 2015 (PBDT 2015) pada kelompok rumah tangga rentan miskin memiliki potensi yang dapat dikembangkan untuk meningkatkan keberdayaan RTS. Pada desil 2 ada 43,18 persen ada anggota keluarga yang memiliki usaha baik sendiri maupun bersama, dan pada desil 3 ada 49,38 persen.

Proses pelaksanaan Program Jalinmatra PK melalui tahapan-tahapan seperti yang telah ditetapkan dalam Pedoman Umum pelaksanaan Program Jalinmatra PK2 yaitu sosialisasi, rembug desa, pembentukan BUMDes, identifikasi potensi, Klarifikasi dan klasifikasi RTS, pembentukan Kelompok Masyarakat (POKMAS), Bimbingan teknis penyusunan rencana usaha, verifikasi dan penilaian kelayakan usaha, pengajuan pencairan bantuan, realisasi pinjaman, bimbingan teknis pengelolaan usaha, pertanggung jawaban dan pelestarian program.

Pada tahap awal baru dapat mengcaver 35 dari total 477 Rumah tangga rentan miskin di wilayah ini. RTS menerima pinjaman tergantung hasil penilaian kelayakan usahanya, sehingga masing-masing RTS menerima pinjaman yang berbeda-beda. Paling banyak jumlah RTS yang menerima pinjaman sebesar Rp.2.000.000,- (54,29 persen) diikuti pinjaman sebesar Rp.4.000.000,(17,14 persen) dan yang paling sedikit RTS yang memperoleh pinjaman Rp.1.500.000,- yang hanya 1 orang atau 2,86 persen). Seperti tampak pada gambar 1 di bawah ini.

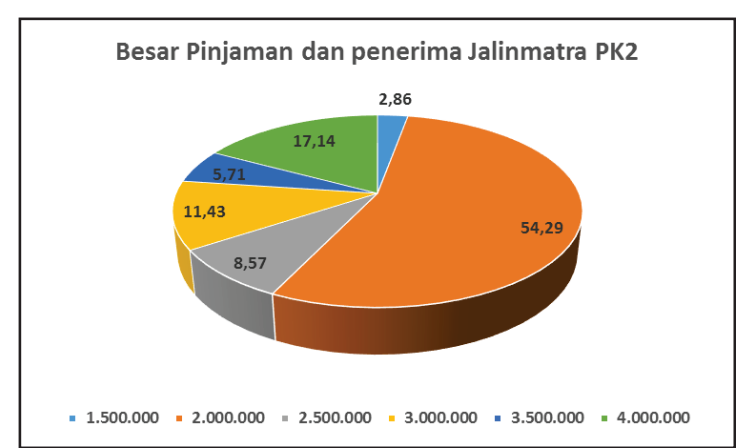

Sumber : Data dari BUMDes Ageng Desa Ngroto diolah

Gambar 1. Diagram persentase RTS penerima program berdasarkan besar pinjaman

Karena pembayaran angsurannya sistem tanggung renteng, maka para RTS tersebut harus membentuk kelompok (POKMAS) dan ketua kelompoknya yang bertanggung jawab pada kelancaran cicilan pinjaman ke BUMDes. Karena variatifnya jenis usaha RTS maka pembentukan POKMAS berdasarkan kewilayahan. Pinjaman yang diterima RTS harus dicicil selama 10 bulan, dengan uang jasa sebesar 0,8 persen per bulan. BUMDes tidak meminta jaminan berupa benda atau surat berharga RTS, namun cukup dengan Surat Nikah sebagai jaminannya. Setiap RTS hanya diberi kesempatan sekali untuk memanfaatkan pinjaman dari Program Jalinmatra PK2, karena harus bergulir ke RTS lain yang belum pernah. Selanjutnya jika masih membutuhkan penguatan permodalan lagi dapat mengajukan pinjaman melalui Pinjaman Usaha Kecil (PUK), yaitu salah satu usaha simpan pinjam yang dikembangkan BUMDes untuk masyarakat umum, baik termasuk dalam kategori RTS maupun tidak, yang memiliki uang jasa relatif lebih besar, yaitu 1 persen per bulan.

Selain setiap RTS penerima pinjaman Jalinmatra PK2 diwajibkan menyisihkan saldo Rp.50.000,- dalam bentuk tabungan di BUMDes. Dana dari tabungan RTS ini diakumulasikan sebagai tambahan modal awal usaha BUMDes selain ada juga penyertaan modal dari Dana Desa. BUMDes Ageng juga menginisiasi bentukbentuk lain dari simpan pinjam dengan sasaran yang berbeda selain Jalinmatra PK2 dan PUK diatas, antara lain :

1. Tabungan Anak Sekolah (TAS) dengan sasaran anak usia sekolah,

2. Tabungan Hari Raya (THR) yaitu tabungan yang hanya dapat dicairkan pada Hari Raya Iedul Fitri,

3. Deposito Berjangka untuk simpanan dalam jumlah dan waktu tertentu,

4. Arisan Sembako, yaitu tabungan yang penarikannya dalam bentuk sembako

5. Pinjaman Pembibitan, yaitu pinjaman yang dikhususkan untuk petani pada saat masa tanam dan pembayarannya pada saat musim panen.

RTS yang belum mendapatkan pinjaman Program Jalinmatra PK2 dapat juga memanfaatkan fasilitas pinjaman yang sudah ada tersebut sesuai bidang usahanya (PUK dan Pinjaman Pembibitan). BUMDes Ageng berkomunikasi dan berkoordinasi dengan unit-unit simpan pinjam lain (Koperasi dan Simpan pinjam di kampung/desa) untuk mencegah kredit macet. 
BUMDes Ageng juga mengembangkan usaha dalam bentuk lain, antara lain :

1. PAM Desa, Pengelolaan air bersih untuk masyarakat desa

2. Agen BNI 46, untuk transaksi setor, tarik tunai dan pembayaran tagihan listrik dan kredit

3. Toko Sembako, yang juga melayani pengambilan Bantuan Pangan Non Tunai (BPNT) yang berupa beras dan telor.

4. Toko Bibit dan Obat-obat Pertanian

Keuntungan dari usaha-usaha BUMDes tersebut selain disetor ke desa sebagai Pendapatan Asli Desa (PAD), sebagian ditambahkan sebagai penguatan modal BUMDes. Sedangkan untuk SP-JMPK2 keuangannya dihitung terpisah, karena harus terus digulirkan untuk RTS lain yang belum dapat, sehingga pada akhir tahun 2017 sudah ada 98 RTS yang sudah menerima pinjaman dari SP-JMPK2. Perkembangan jumlah RTS pemanfaat program SP-JMPK2 dapat dilihat pada gambar 2 di bawah ini.

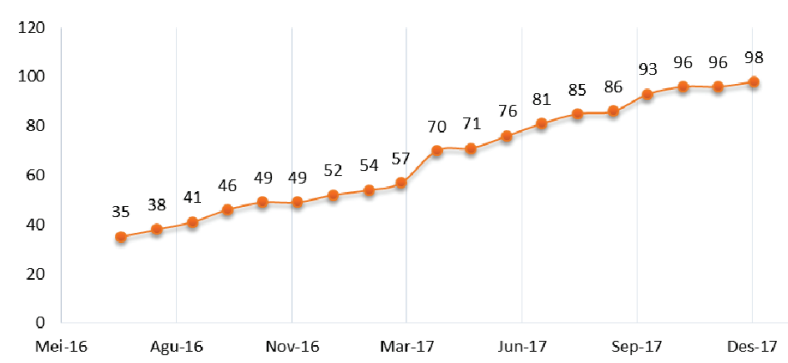

Sumber : Data dari BUMDes Ageng Desa Ngroto diolah

Gambar 2. Jumlah RTS Penerima Pinjaman SPJMPK2 di Desa Ngroto pada Juli 2016 hingga Desember 2017

Pada implementasi Jalinmatra PK2 diketemukan permasalahan di tingkat RTS, antara lain dalam pemilihan bidang usaha RTS banyak yang belum tepat hanya berdasarkan ikut-ikutan saja, tempat tinggal RTS yang memiliki bidang usaha sama cenderung tersebar berjauhan sehingga susah untuk melaksanakan kegiatan penguatan usaha mereka, disamping itu karena aktifitas sehari-hari anggota RTS yang relatif padat untuk kegiatan mencari nafkah sehingga relatif susah untuk mengumpulkan mereka jika akan ada pelatihanpelatihan baik teknis maupun manajemen.

Kemajuan BUMDes Ageng ini dalam mengelola dana Jalinmatra PK2 telah menjadikannya salah satu BUMDes terbaik di tingkat Provinsi Jawa Timur, sehingga menjadi rujukan untuk studi banding BUMDes lain. Dengan kemajuannya juga menjadikannya salah satu tujuan program-program bantuan untuk penguatan BUMDes dari Kementerian Desa, Pembangunan Daerah Tertinggal dan Transmigrasi Republik Indonesia, yaitu dalam bentuk pelatihan dan alat teknologi tepat guna (TTG) untuk pengolahan produksi Bawang Goreng untuk masyarakat (termasuk RTS penerima Jalinmatra PK2).

BUMDes Ageng juga pernah memperoleh pelatihan dari Perguruan tinggi. Universitas Brawijaya Malang pernah memberikan pelatihan pengemasan produk-produk UMKM untuk BUMDes dan masyarakat di Desa Ngroto. Universitas Negeri Sebelas Maret Surakarta juga pernah memberikan pelatihan untuk BUMDes dan masyarakat, berupa pelatihan Desain Grafis (termasuk RTS penerima Jalinmatra PK2).

Jadi dari penjelasan diatas diketahui implementasi program JALINMATRA PK2 di Desa Ngroto telah berjalan dengan baik dalam kurun waktu lebih dari satu tahun ini.

\section{Dampak program JALINMATRA PK2 pada usaha RTS di Desa Ngroto}

30 dari 35 RTS di Desa Ngroto yang pertama menerima bantuan pinjaman modal murah telah kami gali informasinya dengan menggunakan kuisioner. Kami menanyakan pendapatan RTS tersebut sebelum dan setelah mendapatkan bantuan. Selanjutnya kuisioner tersebut kami entri dan olah menggunakan statistik deskriptif.

Hasilnya menunjukkan besarnya peningkatan pendapatan RTS Penerima bantuan pinjaman JMPK2 setelah lebih dari satu tahun menunjukkan paling banyak memperoleh antara 500 ribu hingga 1 juta rupiah sebanyak 12 orang atau 40 persen, diikuti yang kurang dari 500 ribu rupiah sebanyak 11 orang atau 36,7 persen, dan yang paling sedikit adalah yang memperoleh tambahan pendapatan lebih dari 2 juta rupiah, yang hanya 1 orang atau 3,3 persen. Seperti yang ditunjukkan tabel 2 di bawah ini. Dan Jika dirata-rata peningkatan pendapatan RTS Penerima bantuan pinjaman JMPK2 di Desa Ngroto sebesar Rp. 820.556 ,- per rumah tangga per bulan. 
Tabel 2. Peningkatan pendapatan RTS Penerima bantuan pinjaman JMPK2

\begin{tabular}{crr}
\hline $\begin{array}{c}\text { Peningkatan } \\
\text { Pendapatan }\end{array}$ & Jumlah & Persentase \\
\hline$\leq 500$ ribu & 11 & 36,7 \\
\hline 500 ribu $<\mathrm{n} \leq 1$ juta & 12 & 40,0 \\
\hline 1 juta $<\mathrm{n} \leq 2$ juta & 6 & 20,0 \\
\hline$>2$ juta & 1 & 3,3 \\
\hline Total & 30 & 100,0 \\
\hline
\end{tabular}

Sumber: Kuisioner diolah

Dari peningkatan pendapatan yang berhasil diperoleh RTS dari pengelolaan bantuan pinjaman modal tersebut ada 24 orang atau 80 persen yang merasakan sudah dapat membantu memenuhi kebutuhan sehari-hari. Namun masih ada 6 orang atau 20 persen yang masih merasa belum mampu mencukupi kebutuhan sehari-hari rumah tangga mereka. Seperti tampak pada gambar 3 di bawahini.

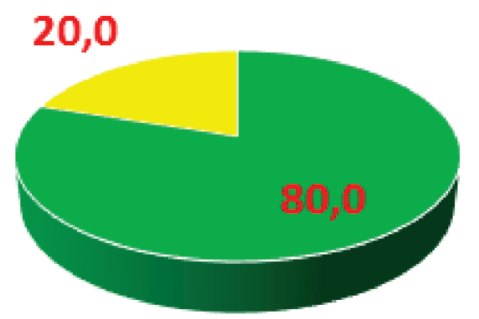

$$
\text { ya tidak }
$$

Sumber : Kuisioner diolah

Gambar3.DampakpadakecukupankebutuhanRTS

Dari besar pinjaman dan peningkatan pendapatan RTS diatas dapat kita ketahui kapasitas atau kemampuan mereka untuk memperoleh keuntungan dari besaran modal yang mereka miliki, dengan mencari prosentase peningkatan pendapatan per besaran tambahan modal per bulan. Dari hasil olah data kita ketahui jika paling banyak RTS memperoleh persentase peningkatan pendapatan per penambahan modal per bulan kurang dari 25 persen sebanyak 16 RTS atau 53,3 persen dan paling sedikit yang memperoleh persentase peningkatan pendapatan per penambahan modal per bulan lebih dari $100 \%$ sebanyak 1 orang atau 3,3 persen. Seperti ditunjukkan tabel 3 di bawah ini.
Tabel 3. Persentase peningkatan pendapatan per penambahan modal per bulan RTS Penerima bantuan pinjaman JMPK2

\begin{tabular}{ccc}
\hline $\begin{array}{c}\text { Persentase Peningkatan } \\
\text { Pendapatan/ Penambahan } \\
\text { Modal/bln }\end{array}$ & Jumlah & Persentase \\
\hline$\leq 25 \%$ & 16 & 53,3 \\
\hline $25 \%<n \leq 50 \%$ & 10 & 33,3 \\
\hline $50 \%<n \leq 75 \%$ & 3 & 10,0 \\
\hline $75 \%<n \leq 100 \%$ & 0 & 0,0 \\
\hline$>100 \%$ & 1 & 3,3 \\
\hline Total & 30 & 100,0 \\
\hline
\end{tabular}

Sumber : Kuisioner diolah

Selanjutnya kami menanyakan kepada para RTS Penerima bantuan pinjaman JMPK2 tersebut keinginan atau hasratnya untuk mengembangkan usahanya. Ternyata sebagian besar RTS tersebut (93,3 persen) memiliki masih keinginan untuk lebih mengembangkan usahanya dan hanya sebagian kecil (6,7 persen) yang tidak memiliki keinginan tersebut. Hal itu tergambar pada gambar 4 dibawah ini.

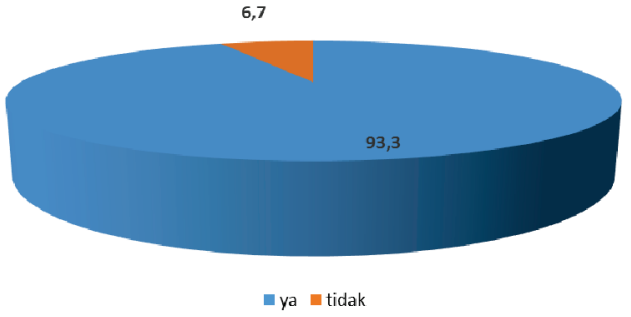

Gambar4. Keinginan RTS Penerima bantuan pinjamanJMPK2 untukmengembangkan usahanya

Sumber : Kuisioner diolah

Strategi optimalisasi program JALINMATRA PK2 di Desa Ngroto

Besarnya keinginan para RTS Penerima bantuan pinjaman JMPK2 untuk lebih mengembangkan usahanya perlu ditindak lanjuti. Usaha yang dikembangkan RTS rata-rata termasuk kategori Usaha Mikro. Karena menurut Undang-Undang Nomor 20 tahun 2008 tentang Usaha Mikro, Kecil, dan Menengah yang dimaksud usaha mikro adalah usaha yang memiliki kekayaan bersih paling banyak Rp. 50.000.000,00 (lima puluh juta rupiah) tidak termasuk tanah dan bangunan tempat usaha; atau memiliki hasil penjualan tahunan paling banyak Rp. 300.000.000,00 (tiga ratus juta rupiah).

Menurut Dun dan Bradstreet dalam Amiaty (2006:9) menyatakan kegagalan usaha kecil 
karena keterampilan bisnis yang tidak memadai, penerapan manajemen yang buruk, banyaknya investasi dalam bentuk asset sehingga menjadi tidak produktif, kegagalan investasi dalam teknologi, arus kas yang tidak memadai. Untuk menurunkan resiko kegagalan dan meningkatkan peluang keberhasilan usaha ini yang menjadi alasan perlunya inkubator bisnis/wirausaha.

Sedangkan menurut Peraturan Presiden Republik Indonesia Nomor 27 tahun 2013 tentang Pengembangan Inkubator Wirausaha, Inkubator Wirausaha adalah suatu lembaga intermediasi yang melakukan proses inkubasi terhadap Peserta Inkubasi (Tenant). Atau dengan kata lain merupakan lembaga yang memfasilitasi dan pengembangan usaha, baik manajemen maupun teknologi untuk meningkatkan dan mengembangkan kegiatan usahanya dan pengembangan produk baru agar dapat berkembang menjadi wirausaha yang tangguh atau produk baru yang berdaya saing.

Untuk memenuhi kebutuhan pengembangan usaha RTS tersebut dibutuhkan faktor-faktor Inkubator bisnis yang oleh Amiaty (20016:11) disebut layanan "7S", antara lain:

1. Space: inkubator menyediakan tempat untuk mengembangkan usaha pada tahap awal.

2. Shared : inkubator menyediakan fasilitas kantor yang bisa digunakan secara bersama, misalnya resepsionis, ruang konferensi, sistem telepon, faksimile, komputer, dan keamanan.

3. Services : meliputi konsultasi manajemen dan masalah pasar, aspek keuangan dan hukum, informasi perdagangan dan teknologi.

4. Support : inkubator membantu akses kepada riset, jaringan profesional, teknologi, internasional, dan investasi.

5. Skill development : dapat dilakukan melalui latihan menyiapkan rencana bisnis, manajemen, dan kemampuan lainnya.

6. Seed capital : dapat dilakukan melalui dana bergulir internal atau dengan membantu akses usaha kecil pada sumber-sumber pendanaan atau lembaga keuangan yang ada.

7. Synergy : kerjasama tenant atau persaingan antar tenant dan jejaring (network) dengan pihak universitas, lembaga riset, usaha swasta, profesional maupun dengan masyarakat internasional.
Dan jika kita uraikan dan kembangkan (Indept interview dan observasi lapangan) faktor-faktor tersebut secara spesifik untuk menunjang pengembangan usaha RTS didapatkan seperti pada tabel 4 berikut ini.

Tabel 4. Faktor-faktor pengembangan usaha/ bisnis RTS Penerima bantuan pinjaman JMPK2

\begin{tabular}{|c|c|}
\hline No & Faktor-faktor Inkubator Bisnis \\
\hline 1 & Tempat yang memadai untuk mengembangkan usaha anda \\
\hline 2 & Bahan baku yang memadai untuk mengembangkan usaha anda \\
\hline 3 & $\begin{array}{l}\text { Teknologi yang memadai untuk mengembangkan usaha anda (alat atau } \\
\text { mesin) }\end{array}$ \\
\hline 4 & Modal yang memadai untuk mengembangkan usaha anda \\
\hline 5 & Tenaga Kerja yang memadai untuk mengembangkan usaha anda \\
\hline 6 & $\begin{array}{l}\text { Pengetahuan tata kelola usaha yang memadai untuk mengembangkan } \\
\text { usaha anda }\end{array}$ \\
\hline 7 & Kemauan/Motivasi untuk mengembangkan usaha anda \\
\hline 8 & Ketrampilan Teknis yang memadai untuk mengembangkan usaha anda \\
\hline 9 & $\begin{array}{l}\text { Ketrampilan Pengelolaan Keuangan yang memadai untuk } \\
\text { mengembangkan usaha anda }\end{array}$ \\
\hline 10 & $\begin{array}{l}\text { Informasi yang memadai untuk mengembangkan usaha anda (produk, } \\
\text { teknologi, pelatihan dan lain-lain) }\end{array}$ \\
\hline 11 & $\begin{array}{l}\text { Pasar atau sarana pemasaran yang memadai untuk mengembangkan } \\
\text { usaha anda }\end{array}$ \\
\hline 12 & $\begin{array}{l}\text { Sarana Komunikasi yang memadai untuk mengembangkan usaha anda } \\
\text { (Telpon/HP/Internet) }\end{array}$ \\
\hline 13 & Konsultasi manajemen pengelolaan usaha \\
\hline 14 & Konsultasi masalah pemasaran \\
\hline 15 & Konsultasi aspek keuangan \\
\hline 16 & Konsultasi aspek hukum \\
\hline 17 & Konsultasi informasi perdagangan \\
\hline 18 & Konsultasi teknologi untuk produksi, komunikasi dan pemasaran \\
\hline 19 & Bantuan akses kepada riset/ penelitian terkait usaha yang anda \\
\hline 20 & $\begin{array}{l}\text { Bantuan jaringan profesional (pengusaha/orang yang sukses di bidang } \\
\text { usaha yang sama dengan anda) }\end{array}$ \\
\hline 21 & Bantuan teknologi produksi, komunikasi dan pemasaran \\
\hline 22 & Bantuan dari Aparatur Desa/Pamong Desa (fasilitasi, modal, pelatihan dII) \\
\hline 23 & Bantuan dari LPMD (fasilitasi, modal, pelatihan dII) \\
\hline 24 & Bantuan dari PKK (fasilitasi, modal, pelatihan dII) \\
\hline 25 & Bantuan dari Karang Taruna (fasilitasi, modal, pelatihan dII) \\
\hline 26 & Bantuan dari LSM (fasilitasi, modal, pelatihan dII) \\
\hline 27 & Bantuan dari Keluarga/saudara (fasilitasi, modal, pelatihan dII) \\
\hline 28 & Bantuan investasi (penanaman modal dari orang lain) \\
\hline 29 & Bantuan internasional (dari luar negeri) \\
\hline 30 & Pelatihan menyiapkan rencana bisnis \\
\hline 31 & Pelatihan menyiapkan manajemen \\
\hline 32 & Pelatihan menyiapkan kemampuan lainnya. \\
\hline 33 & Akses dana bergulir internal \\
\hline 34 & $\begin{array}{l}\text { Bantuan akses usaha kecil pada sumber-sumber pendanaan atau } \\
\text { lembaga keuangan yang ada }\end{array}$ \\
\hline 35 & $\begin{array}{l}\text { Kerjasama atau persaingan dengan pelaku usaha lain yang sama } \\
\text { bidang usahanya dengan anda }\end{array}$ \\
\hline 36 & Jejaring/Kerjasama dengan Perguruan Tinggi \\
\hline 37 & Jejaring/Kerjasama dengan lembaga Penelitian \\
\hline 38 & Jejaring/Kerjasama dengan usaha swasta \\
\hline 39 & $\begin{array}{l}\text { Jejaring/Kerjasama dengan profesional (pengusaha/orang yang sukses } \\
\text { di bidang usaha yang sama dengan anda) }\end{array}$ \\
\hline 40 & Jejaring/Kerjasama dengan masyarakat internasional \\
\hline
\end{tabular}

Sumber : Amiaty (2006:11) dikembangkan 
Selanjutnya dari faktor-faktor tersebut kita gali tingkat kepentingannya dalam mengembangkan usaha RTS Penerima bantuan pinjaman JMPK2 untuk mengetahui dari faktor-faktor tersebut mana yang paling penting (rerata/mean), kita notasikan sebagai $x$. Dan kita pertanyakan kondisi RTS pada faktor-faktor tersebut untuk mengetahui faktor-faktor tersebut mana yang paling kurang (rerata/mean), kita notasikan sebagai y. Sehingga selanjutnya dari hasilnya dapat kita petakan faktor-faktor yang paling dibutuhkan RTS tersebut untuk mengembangkan usahanya $(\mathrm{x})$, tetapi kondisinya kurang (y) dan perlu dibantu oleh pihak lain.

Dari kuisioner pada 30 RTS Penerima bantuan pinjaman JMPK2 diketahui ada 10 faktor yang paling dibutuhkan untuk pengembangan usaha RTS Penerima bantuan pinjaman JMPK2 dari pihak lain antara lain faktor ke 34, 20, 18, 24, 17, 33, 21, 13, 39 dan 28. Seperti tampak pada gambar 5 berikut ini.

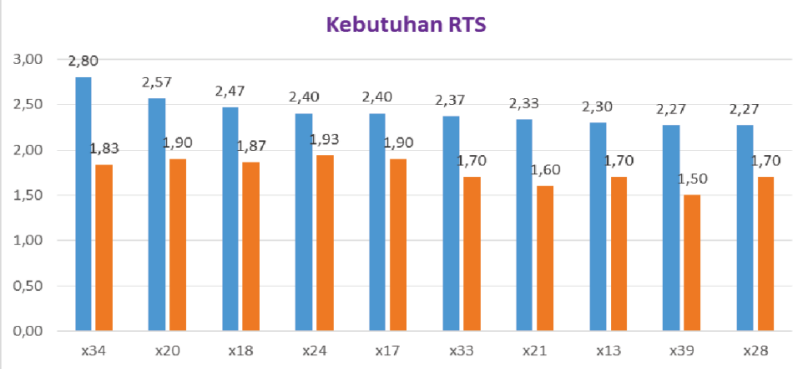

Sumber : hasil kuisioner RTS diolah

Gambar5. Faktor-faktor yang paling dibutuhkan untuk pengembangan usaha RTS Penerima bantuan pinjaman JMPK2 daripihak lain.

Dan jika kita lihat faktor-faktor tersebut meliputi antara lain bantuan akses usaha kecil pada sumbersumber pendanaan atau lembaga keuangan yang ada; Bantuan jaringan profesional; Konsultasi teknologi untuk produksi, komunikasi dan pemasaran; Bantuan dari PKK (fasilitasi, modal, pelatihan dll); Konsultasi informasi perdagangan; Akses dana bergulir internal; Bantuan teknologi produksi, komunikasi dan pemasaran; Konsultasi manajemen pengelolaan usaha; Jejaring/Kerjasama dengan profesional; dan Bantuan investasi (penanaman modal dari orang lain). Seperti yang ditunjukkan pada tabel 5 dibawah ini. Dan jika diringkas menjadi beberapa faktor antara lain penguatan permodalan, teknologi, informasi perdagangan, manajeman usaha dan bantuan jaringan profesional.
Tabel 5. Faktor-faktor yang paling dibutuhkan untuk pengembangan usaha RTS Penerima bantuan pinjaman JMPK2 dari pihak lain (notasi dan uraian).

\begin{tabular}{|c|c|c|c|c|c|}
\hline NO & $\mathbf{x}$ & Bobot & $\mathbf{y}$ & Kondisi & Faktor-faktor \\
\hline 1 & $\times 34$ & 2,80 & y34 & 1,83 & $\begin{array}{l}\text { Bantuan akses usaha kecil pada sumber- } \\
\text { sumber pendanaan atau lembaga } \\
\text { keuangan yang ada }\end{array}$ \\
\hline 2 & $\mathbf{x} 20$ & 2,57 & y20 & 1,90 & $\begin{array}{l}\text { Bantuan jaringan profesional } \\
\text { (pengusaha/orang yang sukses di bidang } \\
\text { usaha yang sama dengan anda) }\end{array}$ \\
\hline 3 & $x 18$ & 2,47 & y18 & 1,87 & $\begin{array}{l}\text { Konsultasi teknologi untuk produksi, } \\
\text { komunikasi dan pemasaran }\end{array}$ \\
\hline 4 & $\times 24$ & 2,40 & y24 & 1,93 & $\begin{array}{l}\text { Bantuan dari PKK (fasilitasi, modal, } \\
\text { pelatihan dII) }\end{array}$ \\
\hline 5 & $\mathbf{x} 17$ & 2,40 & y17 & 1,90 & Konsultasi informasi perdagangan \\
\hline 6 & $\mathrm{x} 33$ & 2,37 & y33 & 1,70 & Akses dana bergulir internal \\
\hline 7 & $\mathbf{x 2 1}$ & 2,33 & y21 & 1,60 & $\begin{array}{l}\text { Bantuan teknologi produksi, komunikasi } \\
\text { dan pemasaran }\end{array}$ \\
\hline 8 & $x 13$ & 2,30 & y13 & 1,70 & $\begin{array}{l}\text { Konsultasi manajemen pengelolaan } \\
\text { usaha }\end{array}$ \\
\hline 9 & x39 & 2,27 & y39 & 1,50 & $\begin{array}{l}\text { Jejaring/Kerjasama dengan profesional } \\
\text { (pengusaha/orang yang sukses di bidang } \\
\text { usaha yang sama dengan anda) }\end{array}$ \\
\hline 10 & $\mathbf{x} 28$ & 2,27 & y28 & 1,70 & $\begin{array}{l}\text { Bantuan investasi (penanaman modal } \\
\text { dari orang lain) }\end{array}$ \\
\hline
\end{tabular}

Sumber : hasil kuisioner RTS diolah

Sehingga strategi yang tepat untuk mengoptimalkan program JALINMATRA PK2 di Desa Ngroto adalah dengan memberikan atau memfasilitasi kebutuhan RTS terhadap faktor-faktor tersebut, atau dibutuhkan strategi khusus Top Down berdasarkan kebutuhan sasaran.

\section{Simpulan}

Berdasarkan analisa dan pembahan diatas dapat ditarik kesimpulan antara lain : (1) Implementasi program JALINMATRA PK2 di Desa Ngroto telah berjalan dengan baik, dari jumlah pemanfaat sudah mencapai 98 RTS dari total 477 RTS yang ada di desa, dari kapasitas lembaga BUMDes telah berkembang dengan berbagai unit usaha. (2) Dampaknya telah berhasil meningkatkan pendapatan RTS Penerima bantuan pinjaman JMPK2 di Desa Ngroto rata-rata sebesar Rp. 820.556,- per rumah tangga per bulan dan mencukupi $80 \%$ kebutuhan RTS. (3) Strategi yang dapat digunakan untuk mengoptimalkan program JALINMATRA PK2 di Desa Ngroto adalah strategi Buttom Up yang berbasis kebutuhan sasaran, yaitu dengan memberikan atau memfasilitasi kebutuhan RTS terhadap faktorfaktor yang paling dibutuhkan untuk pengembangan usaha RTS Penerima bantuan pinjaman JMPK2, antara lain penguatan permodalan, teknologi, informasi perdagangan, manajeman usaha dan bantuan jaringan profesional. 


\section{Saran}

Untuk lebih mengoptimalkan program penanggulangan kerentanan kemiskinan kita perlu lebih memperkuat BUMDes dengan mengembangkan unit-unit yang dapat membantu atau memfasilitasi pengembangan usaha RTS. Perlu adanya kerjasama dan sinergi dengan stakeholder lain terkait optimalisasi program penanggulangan kerentanan kemiskinan dan pengembangan BUMDes. Perlu adanya kajian sejenis di lokasi lain yang memiliki potensi dan karakteristik yang berbeda, sehingga hasilnya dapat lebih aplikatif.

\section{Daftar Pustaka}

Amiaty, Ratna E, 2006, Kajian Inkubator Bisnis dalam Rangka Pengembangan UMKM, Tim Penelitian dan Pengembangan Biro Kredit, $\mathrm{J}$ a ka r a, d i u n d h d a r i https://www.bi.go.id/id/umkm/penelitian/nasi onal/kajian/Pages/riil6.aspx pada tanggal 2501-2018 pukul 12.49 WIB

Anonimous, 2015, Basis Data Terpadu, Tim Nasional Percepatan Penanggulangan Kemiskinan, diunduh dari http://www.tnp2k.go.id/id/tanya-jawab/basisdata-terpadu/ pada tanggal 08-04-2018 pukul19.08 WIB

Anonimous, 2016, Evaluasi Program Kebijakan Jalin matra dalam meningkatkan pendapatan keluarga rentan miskin di Provinsi Jawa Timur, Badan Penelitian dan Pengembangan Provinsi Jawa Timur, Surabaya.

Anonimous, 2017a, Materi Program Jalinmatra 2014-2018, Dinas Pemberdayaan Masyarakat dan Desa Provinsi Jawa Timur.

Anonimous, 2017b, Pedoman Umum Jalin Matra Penanggulangan Kerentanan Kemiskinan (PK2) Provinsi Jawa Timur Tahun 2017, Dinas Pemberdayaan Masyarakat dan Desa Provinsi Jawa Timur.
Dariwardani, Ni Made Inna, 2014, Analisis Dinamika Kemiskinan (Poverty Dynamics) di Bali Berdasarkan Data Susenas Panel 2008 - 2010, diunduh dari https://ojs.unud.ac.id/index.php/jekt/article/vi ew/8769/6549 pada tanggal 21-08-2017 pukul14.49 WIB

Harniati, 2007, Tipologi kemiskinan dan kerentanan berbasis Agroekosistem dan implikasinya pada Kebijakan pengurangan kemiskinan, diunduh dari http://repository.ipb.ac.id/handle/123456789/2 756 pada tanggal 06-09-2017 pukul 02.29 WIB

Nurmawati, Yeni, 2017, Efektivitas Program Jalin Matra Penanggulangan Kerentanan Kemiskinan di Desa Ngroto Kecamatan Pujon Kabupaten Malang, diunduh dari $\mathrm{h} \mathrm{t} \mathrm{t} \mathrm{p}: / / \mathrm{k}$ a $\mathrm{r} \quad \mathrm{y} \quad \mathrm{a}$ ilmiah.um.ac.id/index.php/ekonomipembangunan/article/view/57878 pada tanggal 08-04-2018 pukul 08.38 WIB

Peraturan Presiden Republik Indonesia Nomor 27 tahun 2013 tentang Pengembangan Inkubator Wirausaha

Peraturan Gubernur Jawa Timur Nomor 14 tahun 2017 tentang Pedoman Umum Program Jalan Lain Menuju Mandiri dan Sejahtera Provinsi Jawa Timur Tahun 2017

Undang-Undang Republik Indonesia Nomor 20 tahun 2008 tentang Usaha Mikro, Kecil, dan Menengah

https://jatim.bps.go.id/statictable/2018/01/30/761/ga ris-kemiskinan-makanan-dan-bukanmakanan-di-provinsi-jawa-timur-maret-2008s-d-september-2017-.html diunduh tanggal 03-03-2018 pukul 03.38 WIB 